\title{
DIREITOS SOCIAIS DA POPULAÇÃO TRANSEXUAL E INTERSEXUAL NO BRASIL: EFETIVIDADE POR MEIO DA VINCULAÇÃO ORÇAMENTÁRIA DAS CONTRIBUIÇÕES SOCIAIS
}

\author{
Fábio Eduardo Biazon Abrantes." \\ Kathleen Tie Scalassara. \\ Marlene Kempfer."
}

\section{RESUMO}

A efetivação dos direitos sociais requer recursos públicos. As contribuições sociais previstas nos artigos 195 e 212 da Constituição da República Federativa do Brasil de 1988, são os tributos federais mais adequados para financiar direitos sociais, pois seu regime jurídico impõe vinculação de receitas. Com estas premissas a pesquisa trata dos direitos sociais dos transexuais e intersexuais, ante a atual ausência de políticas públicas com nível de políticas de Estado, para estes cidadãos e cidadãs, especialmente, nas áreas da saúde, assistência social e educação. Para tanto, propõe-se, que será necessário viabilizar uma emenda constitucional.

Palavras-chave: LGBTQIA+. Contribuições Sociais. Seguridade Social. Direitos Humanos. Direito Tributário.

\section{SOCIAL RIGHTS OF THE TRANSSEXUAL AND INTERSEX POPULATION IN BRAZIL: EFFECTIVENESS THROUGH THE BUDGETARY BINDING OF SOCIAL CONTRIBUTIONS}

\begin{abstract}
The effectiveness of social rights requires public resources. The social contributions fixed in the articles 195 and 212 of the 1988's Constitution of the Federative Republic of Brazil, are the most appropriate federal taxes to finance social rights, because their legal regime imposes revenue binding. With these premises, the research is about the social rights of transsexuals and intersexuals, in the absence of public policy at the level of State policies, for these citizens, especially in the areas of health, social assistance and education. To this end, it's proposed that will be necessary to do a constitutional amendment.
\end{abstract}

Key words: LGBTQIA+. Social Contributions. Social Security. Human Rights. Tax law.

\footnotetext{
* Mestrando em Direito Negocial, especialista em direito do estado, com ênfase em tributário, graduado em Direito, todos pela Universidade Estadual de Londrina (UEL). Currículo disponível em <http://lattes.cnpq.br/9786736975021745> ; E-mail: fabio.abrantes@uel.br

** Mestranda em Direito Negocial pela Universidade Estadual de Londrina (UEL), MBA em Gestão e Business Law pela Fundação Getúlio Vargas (FGV), graduada em Direito pela Universidade Estadual de Londrina (UEL). Currículo disponível em <http://lattes.cnpq.br/7430883521387043> ; E-mail: kathleen.tie.scalassara@uel.br

*** Doutora e Mestre em Direito do Estado pela Pontifícia Universidade Católica de São Paulo (PUC/SP). Professora da graduação em Direito e do Programa de Mestrado em Direito Negocial da Universidade Estadual de Londrina. Currículo disponível em <http://lattes.cnpq.br/7141753184018389> ; E-mail: mkempferb@gmail.com
} 


\section{INTRODUÇÃO}

O tema da identidade de gênero sobressaiu-se timidamente nas últimas décadas e ainda na atualidade não compõe a pauta pública brasileira com a mesma importância que as demais questões sociais sobre inclusões, preconceitos e direitos.

Entre as causas possíveis aponta-se a concepção tradicional, ainda fortemente enraizada, na ideia binária de gênero e a dificuldade de admitir outras possibilidades que permitem identificar a pessoa quanto ao gênero, tais quais, trans e intersexual. A falta de conhecimento e a ausência de franco debate sobre esta realidade promovem graves exclusões, em seu sentido mais amplo, com destaque ao acesso e permanência em direitos sociais.

Poucos os governos no Brasil consideraram, explicitamente, estes cidadãos e cidadãs na mesma condição dos demais brasileiros. Os transgêneros e intersexuais são chamados a cumprir seu dever cívico de pagar tributos e contribuem para viabilizar a efetividade de direitos fundamentais sociais, mas, infelizmente, deles pouco ou não usufruem pois dependem da iniciativa de governos ou de imposição judicial para também ter acesso a direitos.

Para enfrentar esta constatação a presente pesquisa, de natureza bibliográfica, defende que os direitos sociais para as populações trans e intersexuais devem ser consideradas políticas de Estado para não ficar à mercê da discricionariedade de políticas de governos, conforme constata-se na atualidade. Neste sentido, para gerar maior segurança jurídica, defende-se que o caminho para alcançar tal nível, política de Estado, deve ser o da Emenda Constitucional no capítulo da Seguridade Social, em especial, nas áreas da saúde, assistência social e educação.

A efetividade destes direitos, em face do princípio financeiro da reserva do possível, dependerá de previsão em orçamento público. Dentre as receitas públicas que o compõe as receitas tributárias são fundamentais. Assim, considerando o regime jurídico dos tributos, sugere-se que a fonte do custeio sejam as contribuições sociais uma vez que têm suas receitas vinculadas a determinadas despesas. Desta forma os argumentos financeiros não mais poderão ser aqueles que, injustificadamente, são utilizados para excluir do usufruto de direitos sociais a população transexual e intersexual no Brasil. 


\section{REALIDADE SOCIAL DA POPULAÇÃO TRANSEXUAL E INTERSEXUAL NO BRASIL}

Ainda permanecem dúvidas quando se pretende identificar a população trans e intersexual. Para tanto é importante pactuar o conteúdo semântico dos termos tais quais: sexualidade, orientação sexual, gênero, intersexualidade, transexualidade e cisgênero.

No que tange à sexualidade esta diz respeito aos aspectos biológicos e genéticos, à própria existência do indivíduo, seus sentimentos e relações interpessoais. Sendo assim, do conceito de Sexualidade infere desdobramentos tais quais o de Gênero e o da Orientação Sexual (CUNHA, 2015, p. 7-38).

A orientação sexual de um indivíduo afere-se pela recepção de estímulos sexuais do sexo oposto (heterossexual) ou do mesmo sexo (homossexual), ou seja, é o interesse "afetivosexual" do indivíduo (CUNHA, 2015, p. 38).

Quanto ao gênero, tem-se um conceito relacionado à percepção social do indivíduo na sociedade. Trata-se de uma construção social advinda da base biológica, que divide os indivíduos em homens ou mulheres. Esta concepção pode ser objeto de contestação tendo em vista estudos que apontam diversas espécies na natureza que não se encaixam na dualidade de gênero ${ }^{1}$; bem como, o reconhecimento estatal, na Alemanha e na Índia, naquele de forma positivada e neste por decisão judicial, de superar o conceito binário de indivíduos (CUNHA, 2015, p. 28).

A intersexualidade é caracterizada por variações genéticas, físicas ou anatômicas do sujeito, podendo ocorrer nos cromossomos, gônadas ou órgãos genitais. Em que pese para ainda seja considerada uma patologia, principalmente devido aos casos de grandes variações no fenótipo do indivíduo, impossibilitando sua classificação nos gêneros binários (homem e mulher), outros consideram a intersexualidade como uma variação genética comum, existentes em todos os indivíduos. Isso pois, conforme se expressou Gerald Callahan, professor da Universidade do Colorado, nos Estados Unidos em entrevista à revista Época (2009), ninguém é $100 \%$ homem, ou $100 \%$ mulher - todos estão no meio.

\footnotetext{
1 “A bióloga Joan Rougharden, da Universidade de Stenford, traz obras como Evolution's Rainbow (Arco-iris da evolução) e The Genial Gene (O Gene Genial), em que destaca inúmeras espécies de mesma natureza que carregam capacidade sexual plena de ambos os sexos, sendo que algumas até mesmo invertem suas funções de macho e fêmea num mesmo acasalamento, concluindo que o intercurso sexual entre animais do mesmo sexo são comuns na natureza" (CUNHA, 2015, p. 28)
} 
A transexualidade é classificada, de acordo com a Organização Mundial de Saúde, em um tipo de transtorno de identidade de gênero, ou seja, caracteriza-se pelo sentimento intenso de não pertencimento ao sexo anatômico, sem a manifestação de distúrbios delirantes e sem bases orgânicas, tal qual a intersexualidade ou qualquer outra anomalia endócrina (BENTO, 2006, p. 120-122).

Em contraposição à ideia de transexualidade, há o cisgênero, ou seja, pessoas cujo gênero é o mesmo que o designado em seu nascimento. Para estes há concordância entre a identidade de gênero e o sexo anatômico de um indivíduo e o seu comportamento ou papel considerado socialmente aceito para esse sexo ${ }^{2} 3$.

$\mathrm{Na}$ atualidade pode-se identificar uma mescla entre as diversas sexualidades (gêneros e orientações sexuais): a) homossexuais cisgênero, os quais se identificam com o sexo de nascimento e sentem atração pelo mesmo sexo; (b) homossexuais transgêneros, que não se identificam com o sexo de nascimento, entretanto sentem atração sexual pelo mesmo sexo que se identificam, e não pelo que nascera; (c) heterossexual cisgênero, que sente atração sexual pelo sexo oposto e se identifica com seu sexo de nascimento; e (d) heterossexual transgênero, que é aquele que não se identifica com seu sexo de nascença e ainda sente atração pelo sexo oposto ao que se identifica (BIAZON, 2016, p. 159).

A realidade destas populações, no Brasil, pode ser avaliada em diferentes e igualmente importantes aspectos. Para estes estudos o enfoque é para denunciar que o Estado e os governos brasileiros atuais não estão suficientemente presente em questões de saúde, violência física e ambiente escolar.

Há dificuldades em apresentar estudos quantitativos sobre as exclusões apontadas, principalmente, por não haver dados estatísticos de fontes oficiais e os estudos disponíveis são de pesquisadores ou grupos autônomos. Estes, constantemente incorrem na grave falta de não criar a estrita distinção entre gênero e sexualidade. O Instituto Brasileiro de Geografia e Estatística (IBGE) sequer possui o segmento para atestar dados brutos acerca da população

\footnotetext{
2 Disponível em: <http://portalarquivos2.saude.gov.br/images/pdf/2016/fevereiro/18/ CARTILHA-Equidade10x15cm.pdf> Acesso em: 05 jun. 2019.

${ }^{3}$ Disponível em: <http://www.defensoria.ba.def.br/wp-content/uploads/2019/01/cartilha_ diversidadesexual.pdf> Acesso em: 05 jun. 2019.
} 
LGBT, mantendo em suas pesquisas apenas os gêneros binários "homem" e "mulher" de modo a desconsiderar as demais identidades de gênero ou mesmo orientações sexuais ${ }^{4}$.

Neste aspecto, apesar da ausência de comprovação estatística, pressupõe-se que a população transexual represente $0,5 \%$ da população, o que seria cerca de um milhão de pessoas ${ }^{5}$. Segundo as informações oficiais da ONU, dentro de suas diversas variações biológicas até $1,7 \%$ da população nasce com características intersexuais, número semelhante à quantidade de pessoas ruivas existentes ${ }^{6}$.

Assim, adentrando na realidade brasileira, nas ações de saúde, observa-se que o Processo Transexualizador está autorizado por meio da Portaria $n^{\circ} 457 / 2008$ do Ministério da Saúde ${ }^{7}$, sendo, em tese, redefinido e ampliado através da Portaria $n^{\circ} 2.803$, de $2013^{8}$. No entanto apenas cinco hospitais brasileiros estão habilitados para a realização do procedimento, segundo art. $9^{\circ}$ da Portaria ${ }^{\circ}$ 2.803/2003, sendo eles o Hospital de Clínicas de Porto (Porto Alegre/RS), Hospital Universitário Pedro Ernesto (Rio de Janeiro/RJ), Hospital de Clínicas da Faculdade de Medicina (São Paulo/SP) e Hospital das Clínicas da Universidade Federal de Goiás (Goiânia/GO).

No gráfico abaixo tem-se dados do Ministério da Saúde ${ }^{9}$ indicando o número de procedimentos cirúrgicos realizados nos últimos 10 anos, nestas cinco das unidades habilitadas a realizar o procedimento:

\footnotetext{
${ }^{4}$ Pode ser observado em seu site oficial através do link < www.ibge.gov.br>.

5 "Esse total de 164 mortes, se referidas a 1 milhão de pessoas trans existentes em nosso país, estimativa referendada pelas próprias associações da categoria, indicam que o risco de uma pessoa trans ser assassinada é 17 vezes maior do que um gay. Já que o IBGE não inclui no censo nacional o segmento LGBT, estimase, com base em indicadores diversos da Academia e Governamentais, que exista no Brasil por volta de 20 milhões de gays $(10 \%$ da população), 12 milhões de lésbicas $(6 \%)$ e 1 milhão de trans $(0,5 \%)$ ". Disponível em: <https://grupogaydabahia.files.wordpress.com/2020/03/relatorio-2018.pdf> Acesso em 29/082020.

${ }^{6}$ Disponível em: <https://www.unfe.org/pt-pt/intersex-awareness/> Acesso em: 29 ago. 2020.

${ }^{7}$ Disponível em: <http://bvsms.saude.gov.br/bvs/saudelegis/sas/2008/prt0457_19_08_2008.html> Acesso em: 05 jun. 2019.

${ }^{8}$ Disponível em: <http://bvsms.saude.gov.br/bvs/saudelegis/gm/2013/prt2803_19_11_2013.html〉 Acesso em: 28 ago. 2020.

${ }^{9}$ Gráficos realizados pela própria fonte citada. Os autores buscaram as informações contidas no gráfico diretamente junto ao Ministério da Saúde, porém os dados não estão mais disponíveis.
} 
Figura 1 - Cirurgia em pessoas trans pelo SUS

Cirurgias em pessoas trans pelo SUS

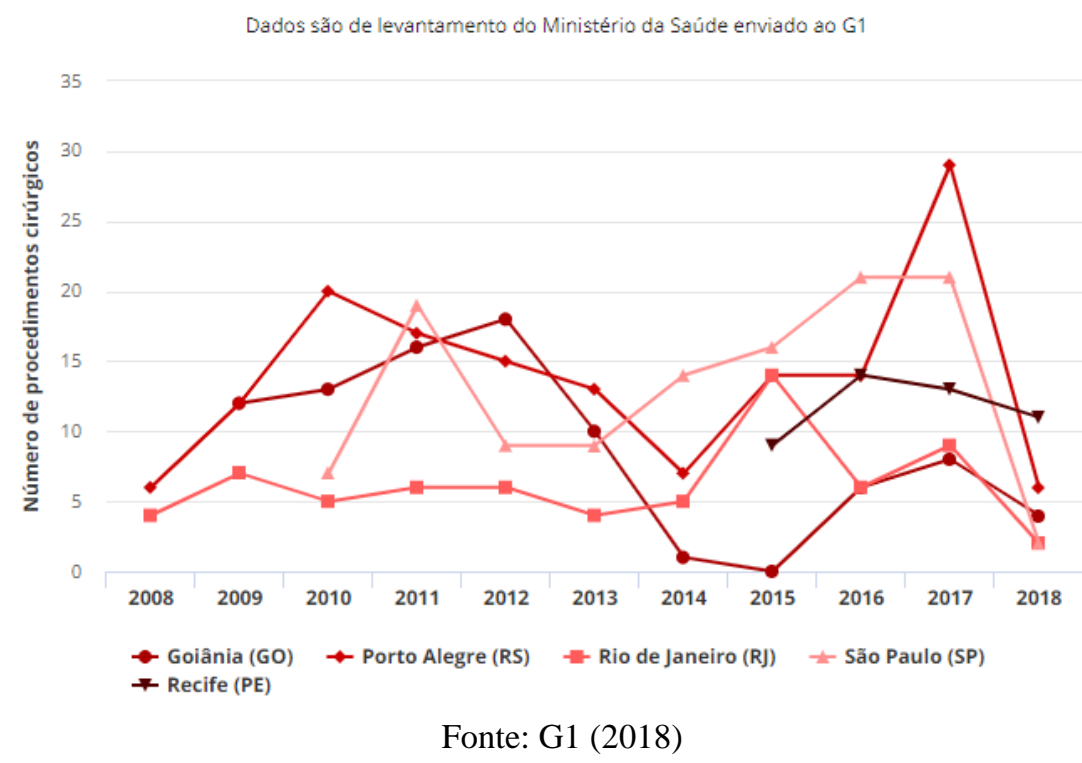

Estes dados apontam que diante da estimativa populacional dos transexuais e o número ínfimo de unidades credenciadas em todo o Brasil o atendimento à tais populações não foi prioridade dos diferentes governos no período considerado. Ressalta-se, assim, "um modelo de atenção à saúde biomédico e curativista" que "não será capaz de responder às demandas em saúde da população trans" (ROCON; et.al. 2018, p.43).

No que tange à violência física enfrentada por esta parcela da população, segundo dados da ONG Transgender Europe (TGEU), o Brasil segue no primeiro lugar do ranking de assassinatos de transexuais, registrando 802 homicídios de 2008 a 2015. Este número é superior ao número de mortes somadas dos outros 22 países que tiveram seus dados colhidos, que é de 771 mortes, totalizando 1.573 assassinatos ${ }^{10}$.

Os dados públicos ${ }^{11}$ obtidos por meio do sistema de denúncia Disque 100 do Ministério dos Direitos Humanos (MDH), referência para elaborar políticas públicas pelo governo federal, traz o seguinte gráfico que contêm as taxa de denúncias por 100 mil habitantes entre os anos de 2011 a 2018 no Brasil:

10 Disponível em: <https://transrespect.org/wp-content/uploads/2016/03/TvT_TMM_TDoV2016_Tables_ EN.pdf> Acesso em: 29 ago. 2020.

${ }^{11}$ Os dados foram elaborados pela FGV DAPP, com acesso pela última vez em 17/05/2019 e estão disponíveis através do link <http://dapp.fgv.br/dados-publicos-sobre-violencia-homofobica-no-brasil-29-anos-de-combateao-preconceito/>, no entanto, não foi possível a extração das informações diretamente do site governamental uma vez que as informações não estão mais disponíveis. 
Figura 2 - Série temporal da taxa de denúncias por 100 mil habitantes entre os anos de 2011 a 2018 no Brasil

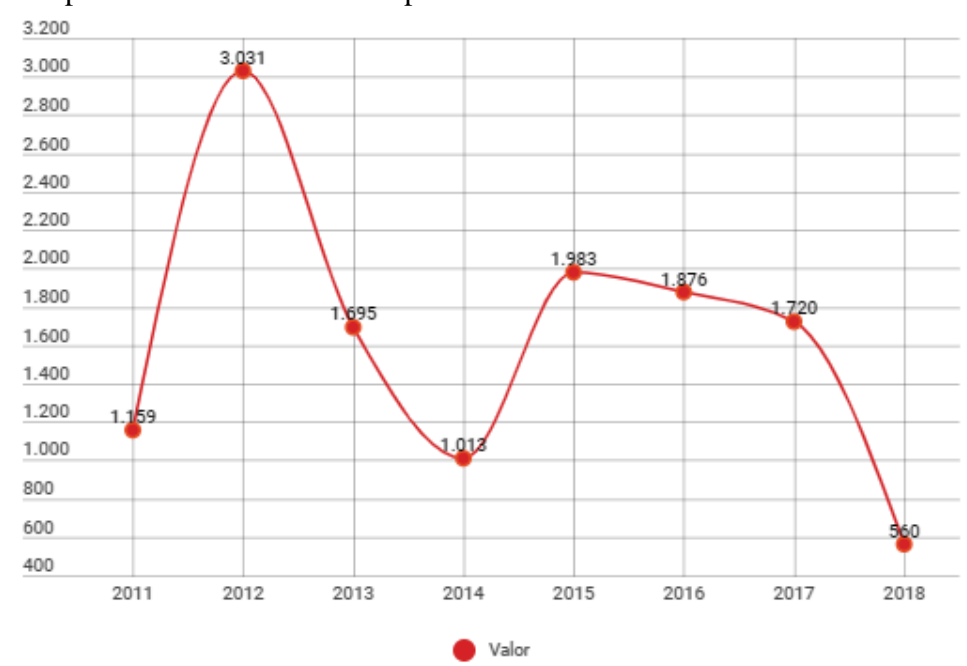

Fonte: FGV DAPP, 2018.

Segundo Relatório Sobre Violência Homofóbica no Brasil ano de 2012, elaborada pela biblioteca do Ministério da Justiça ${ }^{12}$, a violência contra "travestis e transexuais seguem sendo as maiores vítimas de violência homofóbica e justamente as violências de maior gravidade como homicídios e lesões corporais". Ademais, indicam que as reduções de violência indicadas nos gráficos, decorreram de campanhas de sensibilização realizadas pelo governo federal. Conforme os gráficos da ONG Grupo Gay da Bahia - GGB que faz o mapeamento dos casos de homicídios contra a população LGBT $^{13}$, em 2018 registrou-se 420 mortes de LGBT no país:

\footnotetext{
12 Disponível em: <http://www.rcdh.es.gov.br/sites/default/files/RELATORIO\%20VIOLENCIA\%20 HOMOFOBICA\%20ANO\%202012.pdf> Acesso em: 31 ago. 2020

${ }^{13}$ Disponível em: <https://grupogaydabahia.files.wordpress.com/2020/03/relatorio-2018.pdf> Acesso em 29 ago. 2020.
} 
Figura 3 - Pessoas LGBT mortas no Brasil por ano

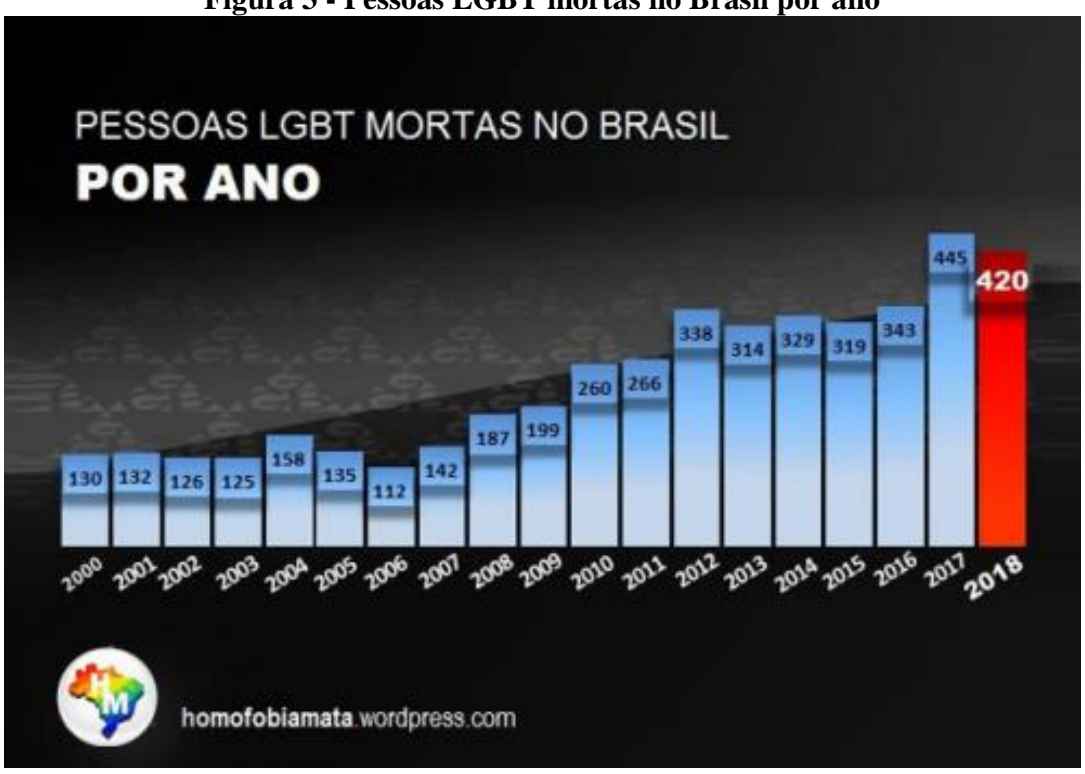

Fonte: GGB, 2018.

Neste mesmo aspecto a ONG GGB indica que em $2017^{14}$ a cada 19 horas e em $2018^{15}$ a cada $20 \mathrm{~h}$ registrou-se um novo caso de homicídio contra essa população. Isso coloca o Brasil, segundo a GGB, como o campeão mundial de violência contra minorias sexuais. Como exemplo cita que "enquanto nos Estados Unidos, com 330 milhões, mataram-se no ano passado 28 transexuais, no Brasil, com 208 milhões de habitantes, registraram-se 164 mortes: o risco de uma trans brasileira ser assassinada é 9 vezes maior do que as americanas" (GGB, 2018).

Ressalta-se que segundo os dados da ONG GGB (2018), a população transexual se mostra mais vulneráveis às mortes violentas, indicando chances 17 vezes maiores de serem assassinadas em relação à população gay.

Quanto as questões que envolvem a assistência social a discriminação está presente, em especial nas relações de família. Esta população, nos termos do artigo 226 , § $5^{\circ}$, da $\mathrm{CF} / 88$, nem mesmo pode ser considerada sociedade conjugal pois no texto reconhece como tal a relação entre homem e mulher.

No que tange às profissões, a ONG Grupo Gay Bahia traz os dados em que 2018 foram assassinadas 83 travestis e transexuais na pista ou em locais usuais de prestação de

\footnotetext{
${ }^{14}$ Disponível em: <https://grupogaydabahia.files.wordpress.com/2020/03/relatorio-2017.pdf> Acesso em 29 ago. 2020.

${ }^{15}$ Disponível em: <https://grupogaydabahia.files.wordpress.com/2020/03/relatorio-2018.pdf> Acesso em 29 ago. 2020.
} 
serviços sexuais, 33 estudantes, 26 cabeleireiras, 13 professores, 10 pais de santo e padre, 7 comerciantes e 7 vendedores ${ }^{16}$. Estes dados expõem as condições de extrema violência que estão expostos, permitindo concluir que são, praticamente, inimpregáveis.

Ao analisar se existem estratégias de algumas entidades para promover o acesso ao trabalho para a população transexual e travesti, Almeida e Vasconcellos (2018), concluíram que não houve muitas experiências positivas, salvo quando houve intervenção judicial:

\begin{abstract}
no Brasil, apesar de o trabalho ser considerado um direito social, o emprego formal não faz parte da vida da população trans. Estima-se que em torno de $90 \%$ das mulheres travestis e transexuais se prostituam, apesar de não haver dados oficiais consistindo a prostituição fonte de renda para quem "não conquistou outros espaços" (REIDEL, 2013, p. 74-75). Também os homens trans têm dificuldades para se inserir no mercado de trabalho formal. (ALMEIDA, VASCONCELLOS, 2018, s/n)
\end{abstract}

Quanto a educação, inúmeros são os casos de discriminação no ambiente escolar. Para ilustrar tem-se dados coletados por Macedo (2019), que teve como objetivo geral avaliar a existência da Violência de Gênero no ambiente escolar de três municípios do Cariri Paraibano. Em que pese em alguns de seus aspectos tenha privilegiado as questões relativas a orientação sexual, em detrimento das relativas à identidade de gênero, a pesquisa manteve a escolha de participação aberta entre os alunos de 15 a 19 anos de idade. Os resultados apontam que: $78 \%$ das entrevistas se identificaram com o sexo feminino; $20 \%$ com sexo masculino; e, 2\% não se identificaram; 79\% destes se reconhecem como heterossexuais; e, $21 \%$ afirmaram se identificar como LGBTQIAP+.

A pesquisadora indica que apesar de $87 \%$ das pessoas entrevistadas negarem qualquer incomodo ao ver um casal homossexual, os comportamentos observados destes na presença de homossexuais são divergentes. Ademais, 68\% indicaram já ter presenciado casos de alguma forma de preconceito perpetrado no ambiente escolar, sendo que $63 \%$ por cento responderam já terem sofrido pessoalmente alguma forma de preconceito. Quanto aos professores e sua capacitação, 99\% deles responderam jamais ter recebido qualquer capacitação para tratar acerca de questões de gênero.

A pesquisa conclui afirmando que apenas uma das escolas entrevistadas se mostrou aberta para debater a diversidade de gênero, porquanto as outras duas deixam de tratar diretamente sobre o tema, sendo que em uma delas houve expressa afirmativa de que o tema não é debatido pois é bem aceito, no entanto, apesar do discurso, a realidade prática

16 Disponível em: <https://grupogaydabahia.files.wordpress.com/2020/03/relatorio-2018.pdf> Acesso em 29/082020. 
demonstrou não apenas a presença da homofobia, mas também a constante encoberta realizada pelas instituições.

Estes e outros dados ${ }^{17}$ expõem que o preconceito e o desconhecimento estão presentes, inclusive, em ambiente onde deveria ser o espaço do conhecer e acolhimento. Neste sentido, confirma-se a importância de uma educação inclusiva, por meio do diálogo, em todos os espaços públicos. Para tanto, defende-se, não é mais possível deixar esta realidade na condição de política de governo. Precisa ser elevada à política de Estado.

\section{POLÍTICAS PÚBLICAS DE ESTADO E DE GOVERNO}

O atual cenário político brasileiro requer uma análise estrita quanto a necessidade de Políticas Públicas que assegurem e efetivem os direitos sociais da população Transexual e Intersexual. Para tanto sugere-se a criação de Políticas Públicas de Estado e não apenas Políticas de Governos. Aquelas representam um dever jurídico constitucional para todos os governos e o seu desrespeito possibilita a intervenção judicial por omissão constitucional na entrega dos direitos fundamentais dos trans ou intersexuais.

O surgimento das Políticas Públicas remonta às novas necessidades da sociedade contemporânea após a consolidação dos aglomerados urbanos e do processo de industrialização. Tal cenário de livre concorrência, deu lugar a condições de trabalho duríssimas e inumanas, ressaltando a escassez de direitos individuais quando a "democracia política não se convertia em democracia social" (TRUYOL y SERRA, 2000, p.31, apud. APPIO, 2005, p. 142-143).

Segundo Emílio Garcia (1999, p. 139, apud. APPIO, 2005, p. 143), as novas necessidades sociais se convertem em "declarações setoriais", isto é, representam as reivindicações de um setor específico da sociedade, com suas próprias e concretas problemáticas que os discriminam do restante da população.

\footnotetext{
${ }^{17}$ A professora Fernanda Vedrossi (2013, online) realizou pesquisa a fim de identificar as violências sofridas por pessoas transgêneros no ambiente escolar. Para tanto considerou a resposta de adolescentes (17\%), jovens (54\%) e adultos (29\%), sendo que entre estes $28 \%$ representa pessoas de gênero masculino, $28 \%$ feminino, $29 \%$ não binário ou fluido, $10 \%$ transexual e 5\% homossexual. Apurou, nesta amostragem, que $90 \%$ já sofreu violência ou preconceito no ambiente escolar em razão de sua condição como travesti ou transgêneros. Quanto ao tipo de violência, $69 \%$ tratou-se de violência física, $21 \%$ violência verbal e $10 \%$ violência velada. A agressão operou-se $52 \%$ por parte de outros alunos, $23 \%$ por parte dos professores, $16 \%$ por outros funcionários. Ainda, após a violência 34\% destes não obtiveram qualquer tipo de ajuda, $35 \%$ recebeu ajuda de amigos e outros alunos, em contrates à ajuda por parte de professores, diretores e outros funcionários da escola, que se deu em apenas $25 \%$.
} 
Em decorrência dessa realidade Reinaldo Pereira e Silva (1998, p. 45 apud. APPIO, 2005, p. 145) atesta que a única forma de autopreservação dessa sociedade capitalista, a fim de reduzir as desigualdades sociais, foi o investimento no Estado intervencionista. Este foi construído para viabilizar direitos, entre eles, os sociais que promovem inclusões:

\begin{abstract}
A inversão de recursos públicos nas áreas sociais, como saúde e educação está ligada ao desenvolvimento do país, assegurando-se aos cidadãos as condições mínimas de inserção num mundo globalizado, onde não tem espaço para pessoas que não tenham tido acesso à instrução fundamental e à saúde básica. O espaço adequado para que todos estes direitos sejam garantidos é justamente aquele traçado pela Constituição de 1988, quando se refere aos seus objetivos fundamentais(...): desenvolvimento e democracia (APPIO, 2005, p. 147).
\end{abstract}

As Políticas Públicas são alternativas do Estado-providência e se designam como um conjunto de ações jurídicas do Estado voltadas ao cumprimento dos seus objetivos sejam eles gerais ou setoriais. A atuação estatal se dá pela articulação das diversas nuances da sociedade e da economia, visando não só a coerência e a eficiência, mas também racionalidade da ação governamental (APPIO, 2005, p. 133-134).

Podem ser conceituadas, portanto, como instrumentos de execução de programas políticos baseados na intervenção estatal na sociedade com a finalidade de assegurar a igualdade de oportunidades aos cidadãos (APPIO, 2005, p. 136).

Será por meio das Políticas Públicas que o Estado atuará afim de efetivar seu dever constitucional de equidade. Criará maneira efetivas de igualar as condições de uma minoria desprivilegiada em relação ao restante da população.

A efetivação das Políticas Públicas, defende-se, ocorrerá com maior margem de segurança quando galgarem a condição de Política de Estado. Políticas de Governo, representam a atuação do poder público, por meio de seu governante em seu período de mandato. Políticas de Estado compõem o conjunto de deveres públicos previstos em nível constitucional e sobre os quais os governos não tem alternativa de cumprir ou não. Há a obrigação de previsão orçamentária para garantir sua efetividade. Por este caminho retira-se a discricionariedade do chefe-de-estado em implementá-las ou não, pois todos os governantes devem respeitas os preceitos constitucionais.

Os direitos da população trans ou intersexual encontram-se implícitos na Constituição Federal de 1988 e sua efetividade dependem de Políticas de Governo. Esta população fica refém das prioridades de gestores que, infelizmente, poderão estar enraizados no tradicionalismo intolerante e preconceituoso. Neste caso, é grande o risco de retrocessos. 
Para elucidar a necessidade de uma Política de Estado tem-se o mandamento constitucional de 1988 que tratou de garantir os recursos necessários ao financiamento da saúde e da educação por meio de um sistema automático de repasses, eliminando a discricionariedade do Poder Executivo quando da formulação da lei orçamentária. Segundo Eduardo Appio (2005, p. 147), a forma de investir destes recursos será determinada pela sociedade, por meio de Conselhos previstos em lei como, os conselhos municipais de saúde e conselhos municipais da criança e do adolescente.

Um aspecto relevante da discussão sobre a omissão do Estado em garantir Políticas Públicas, decorre da constatação de frequente judicialização de demandas em que trans ou intersexuais reivindicam direitos que lhe foram tolhidos e com o escopo de garantir a obrigatoriedade em sua implementação pelo Executivo.

O controle judicial das políticas públicas no país emerge do interior de uma sociedade fragmentada pelas desigualdades sociais e marcada pela limitação decisória imposta aos mecanismos tradicionais de repressão do estado (APPIO, 2005, p. 137).

Argumenta-se a necessidade de serem criadas Políticas Públicas de Estado para assegurar distribuição igualitária das receitas públicas para viabilizar direitos àqueles que se encontram em situação menos favorecida. Este caminho, por certo, contribuirá para diminuir os números de judicializações.

\section{CUSTO DOS DIREITOS, TRIBUTAÇÃO E O FINANCIAMENTO DOS DIREITOS SOCIAIS}

Com a crise do Estado-Mínimo Liberal, em que a função do Estado era essencialmente garantir a liberdade, propriedade e a segurança, florescem as possibilidades do Estado Social. Junto com este os direitos sociais são enaltecidos e fica explícito a nova obrigatoriedade do Estado em implementar políticas públicas que efetivassem os direitos fundamentais positivados.

Para a efetividade de qualquer das dimensões de direitos fundamentais é necessário que sejam garantidos recursos orçamentários públicos. Tais recursos serão obtidos especialmente por meio da sua competência de instituir, arrecadar e fiscalizar tributos. Na medida em que aumentam as atribuições estatais se tornou imperioso eficiência da 
arrecadação. De modo que, entre os pilares para a concretização do Estado Democrático de Direito, está a tributação (MOREIRA, 2015, p. 43).

\subsection{Custo do dos Direitos}

Há um importante debate, em face do princípio financeiro da reserva do possível, em torno de defender qual a melhor forma de atuação estatal frente às suas diversas competências. Tem-se argumentos que expõem temor diante dos gastos públicos de um estado assistencial e outros que acreditam em um estado solidário e generoso para auxiliar a todos que dele necessitam.

Neste contexto destaque-se para esta pesquisa os argumentos de Stephen Holmes e Cass. R. Sustein na obra "El costo de los derechos: Por qué la liberad depende de los impuestos" (2012), em que há importantes argumentos quanto ao que representa de custo ao Estado cumprir com seu dever de proteger os direitos individuais, em especial, a tutela do direito da propriedade privada, liberdade e segurança individual e de defesa da soberania nacional. Para tais competências há necessidade de uma estrutura estatal de elevados custos.

Investir em direitos sociais é seguro, entre eles, aqueles que promovem a redução das desigualdades socioeconômicas, a erradicação da miséria, educação e saúde universal e gratuita, promoção das culturas que permitem reforçar a identidade do indivíduo. Estes investimentos poderão diminuir os investimentos para garantia dos direitos individuais supra referidos.

Do conflito indicado pelo autor entre direitos negativos e direitos positivos, sendo o primeiro aquele permitidos, mas não financiados pelo Estado, e o segundo aqueles que o Estado deverá provisionar ante a necessidade de sua existência, intenciona-se dizer que as Políticas Públicas ora explanadas, considerando o atual status da população Transexual e Intersexual, bem como os preceitos e fundamentos constitucionais, adequam-se de forma contundente às imposições de um direito positivo.

No Brasil tem-se que a própria Constituição de 1988, à luz do Princípio da Isonomia, aponta para a redistribuição de renda, de modo igualitário, conforme explicita o Art. $145, \S^{\circ}$ da CF:

Sempre que possível, os impostos terão caráter pessoal e serão graduados segundo a capacidade econômica do contribuinte, facultado à administração tributária, especialmente para conferir efetividade a esses objetivos, identificar, respeitados os direitos individuais e nos termos da lei, o patrimônio, os rendimentos e as atividades econômicas do contribuinte. 
Nas palavras de Paulo Barros de Carvalho (2015, p. 292), a tributação poderá indicar os parâmetros para concretizar o ideário constitucional de equidade e isonomia:

Isso não significa, contudo, que todos os contribuintes deverão receber tratamento tributário igual, mas, sim, que as pessoas, físicas ou jurídicas, encontrando-se em situações econômicas idênticas, ficarão submetidas ao mesmo regime jurídico, com as particularidades que lhe forem próprias.

Defende-se que o objetivo constitucional não se limita à preocupação com capacidade contributiva do indivíduo, mas, também, com que haja uma diminuição nas desigualdades sociais e a desconcentração de renda.

É conferido à lei tributária desigualar situações, atendendo a peculiaridades de categorias de contribuintes (...) O princípio da isonomia é agredido quando o tratamento diverso (...) não encontra motivo razoável (CARVALHO, 2015, p. 296).

O dever de pagar tributo surge do pacto social a fim de cumprir com os direitos e as garantias fundamentais (MOREIRA, 2015, p. 44). Nestes termos, o Estado é a única instância capaz de unir formas para a efetivação de direitos, em especial, os direitos sociais. Este Estado garantidor tem um custo e deverá ser financiado pela população na condição de contribuinte.

\subsection{Direitos sociais da seguridade social}

A Constituição da República Federativa do Brasil de 1988 é reconhecidamente garantidora dos direitos individuais e sociais. Ela representa o alicerce dos direitos humanos como nenhuma outra havia sido no Brasil.

Neste sentido o legislador constitucional tinha conhecimento dos altos custos dos direitos e estabeleceu uma tributação correspondente, ou seja, "A tributação surge como alternativa do Estado para fomentar o desenvolvimento nacional, cujo conceito deve abarcar de forma especial a redução das desigualdades regionais e sociais” (ELALI, 2007, p. 24). Estes, defende-se são pressupostos para que o indivíduo consiga usufruir dos demais direitos. Esta relevância está explícita no texto da atual Constituição nos termos do Art. $6^{\circ}$ e no título que trata da Seguridade Social.

A Seguridade Social está prevista no capítulo sobre a Ordem Social, onde consta expressamente que o objetivo é proporcionar o bem-estar e a justiça sociais, conforme art. 194, CF, in verbis: 
Art. 194. A seguridade social compreende um conjunto integrado de ações de iniciativa dos Poderes Públicos e da sociedade, destinadas a assegurar os direitos relativos à saúde, à previdência e à assistência social.

Compreende os direitos relativos à saúde as medidas destinadas à redução do risco de doenças e de outros agravos, além de o acesso universal e igualitário às ações e serviço estatais que promovam a proteção e recuperação da população. Tais direitos serão garantidos por meio de políticas sociais e econômicas, conforme leciona Pedro Lenza (2009, p. 758). Sendo que, por se tratar de tema de relevância pública, conforme Art. 197 da CF, deverá o Poder Público regular, fiscalizar, controlar e promover a execução, seja diretamente ou por terceiros (pessoa física ou jurídica de direito privado).

Os direitos da previdência são de caráter contributivo e de filiação obrigatória sendo vedado a adoção de requisitos e critérios diferenciados para a concessão de aposentadoria aos beneficiários do regime geral de previdência social, salvo condições prejudiciais de trabalho, e quando se tratar de segurados deficientes. Esta atenderá conforme os seguintes preceitos: (a) cobertura dos eventos de doença, invalidez, morte e idade avançada; (b) proteção à maternidade, especialmente à gestante; (c) proteção ao trabalhador em situação de desemprego involuntário; (d) salário-família e auxílio-reclusão para os dependentes dos segurados de baixa renda; (e) pensão por morte do segurado, homem ou mulher, ao cônjuge ou companheiro e dependentes (MORAES, 2017, p. 607).

Os direitos à assistência social, compreendem (a) a proteção à família, à maternidade, à infância, à adolescência e à velhice; (b) o amparo a crianças e adolescentes carentes; (c) a promoção da integração ao mercado de trabalho; (d) a habilitação e reabilitação das pessoas portadoras de deficiência e a promoção de sua integração à vida comunitária; (e) a garantia de um salário mínimo de benefício mensal à pessoa portadora de deficiência e ao idoso que comprovem não possuir meios de prover a própria manutenção ou de tê-la provida por sua família, conforme dispuser a lei (MORAES, 2017, p. 610). Ela será prestada a quem dela necessitar, dada sua natureza não contributiva, ou seja, independe de contribuição à previdência social. A mesma será financiada, principalmente, pelo orçamento da Seguridade Social, além de outras fontes (LENZA, 2009, p. 761).

A viabilidade destes direitos depende, fundamentalmente, de recursos advindos da tributação. Entre os tributos previstos no Sistema Tributário Nacional destacam-se as Contribuições Sociais e seu regime de vinculação de receitas. 
A decisão do legislador constituinte de vincular a arrecadação para determinadas despesas, permite afirmar que tais direitos devem ser qualificados de especiais e galgar o nível de direitos a compor Políticas de Estado. Sendo assim, fogem da discricionariedade de governos em implementá-las.

\section{CONTRIBUIÇÕES SOCIAIS}

As Contribuições Sociais serão as responsáveis por financiar a Seguridade Social prevista no Art. 195 da CF, sendo que competência para sua instituição é exclusiva da União conforme estipulado pelo Art. 149 da Carta Magna

Tais contribuições são espécies de tributos com regime diferenciado no sentido de que suas receitas estão previamente destinadas: custear os direitos que compõe a seguridade social. Acrescente-se a possibilidade de outra contribuição, a contribuição social do salárioeducação, para financiar educação básica conforme art. 212, § 5 da CF/88.

A origem das contribuições remonta à passagem do Estado Fiscal, estado em que as necessidades financeiras são essencialmente suportadas por imposto (para o estado Liberal, que trouxe a ideia de proteção da propriedade e das liberdades do indivíduo), mas este apenas seria pago em razão de benefícios obtidos (justiça comutativa) (FERRARO, 2018, p. 3).

No Século XX, com o desenvolvimento do Estado Social, e o conceito de liberdade positiva $^{18}$, arquitetou-se a sistemática de que que todos devem ter seus direitos garantidos, inclusive os sociais. É o momento do ideário de justiça distributiva e da solidariedade, alargando a base tributária e para estender a tributação à toda a população, como o escopo de financiar ações estatais como saúde pública e educação, “caracterizando-se, portanto, num estado economicamente interventor e socialmente conformador” (FERRARO, 2018, p. 3). São os fundamentos das contribuições.

Num terceiro momento, reavaliou-se os valores de liberdade e solidariedade. Houve uma tentativa de unir os elementos de justiça comutativa com os da justiça distributiva, possibilitando chegar em uma solidariedade de grupo, vinculando contribuições parafiscais através da referibilidade de grupo, conforme afirmou Ferraro (2018, p. 4). Assim, a tributação passou a ter um fundamento específico e arrecadação vinculada à uma finalidade.

\footnotetext{
${ }^{18}$ Ideia de ter, não só, o poder para agir, mas também os recursos necessários para tal.
} 
Tal separação deu origem à discussões sobre a natureza jurídica das contribuições não ser tributária, mas algo à parte. Essa realidade foi formalizada no ordenamento jurídico pátrio pela $\mathrm{EC} \mathrm{n}^{\circ} 8$, que modificava a $\mathrm{CF}$ de $1967^{19}$, em que pese as contribuições já tivessem constado expressamente na Constituição de 1934.

Com o advento da Constituição de 1988 e com seu viés intervencionista acabou por transmutar a parafiscalidade em fiscalidade e conferiu às contribuições sociais natureza jurídica de tributo, conforme Artigo 149. Neste sentido, bem se expressa Ferraro, (2018, p. 7):

Esta simbiose é facilmente identificada nas contribuições para a seguridade social, haja vista que os artigos 193 e seguintes da CFRB/88 qualificam os fins a serem perseguidos, o que as aproxima do ideal do Estado Social, enquanto o artigo 149 remete ao Estado de Direito ao obrigar tais contribuições a se submeterem, dentre outras, às limitações ao poder de tributar.

Com fundamento na solidariedade a responsabilidade para custear, em sentido amplo, para a efetividade dos direitos sociais será de determinado grupo de pessoas físicas ou jurídicas serão responsáveis pelo pagamento das Contribuições Sociais, além de outros meios de participação, ou seja, instituições ou pessoas que atuem no terceiro setor e também a participação do Estado por meio dos orçamentos fiscais:

Art. 195. A seguridade social será financiada por toda a sociedade, de forma direta e indireta, nos termos da lei, mediante recursos provenientes dos orçamentos da União, dos Estados, do Distrito Federal e dos Municípios, e das seguintes contribuições sociais:

O rol de fontes de custeio previstos no Art. 195 da CF é exaustivo e, segundo o $\S 4^{\circ}$, somente Lei Complementar poderá instituir novas fontes para o custeio da Seguridade Social. Há previsão no $\S 7^{\circ}$ de isenção para entidades beneficentes de assistência social, nos termos da legislação infraconstitucional.

Cabe ressaltar ainda que Estados, do Distrito Federal e Municípios terão receitas próprias, desatreladas ao orçamento da União, devendo, no entanto, quando da elaboração da proposta de Orçamento da Seguridade Social, obedecer a Lei de Diretrizes Orçamentária, em conformidade com os $\S \S 1^{\circ}$ e $2^{\circ}$ do Art. 195 da CF.

\footnotetext{
${ }^{19}$ Carolina Cantarelle Ferraro (2018, p. 5 e 6) explica que "nem a redação original do Código Tributário Nacional (CTN) e da Constituição de 1967 tratavam da figura das contribuições. Tanto é que foi necessário o advento do Decreto-lei ${ }^{\circ}$ 27/1966 para inclusão do artigo 217 no CTN ratificando a permanência das contribuições no ordenamento constitucional, bem como a Emenda Constitucional (EC) $n^{\circ} 01 / 1969$, fazendo referência expressa a tal figura mediante a inclusão do parágrafo $2^{\circ}$ e inciso I no artigo 21 da Constituição de $1967 "$
} 
Destaque-se que não são apenas as Contribuições Sociais as responsáveis para fazer frente às políticas sociais, isso pois “os tributos não vinculados, como os impostos, poderão ser eventualmente aplicados para custeio de políticas sociais" (MOREIRA, 2015, p. 47), conforme Art. 167, da Constituição Federal de 1988:

\footnotetext{
Art. 167. São vedados:

IV - a vinculação de receita de impostos a órgão, fundo ou despesa, ressalvadas a repartição do produto da arrecadação dos impostos a que se referem os arts. 158 e 159, a destinação de recursos para as ações e serviços públicos de saúde, para manutenção e desenvolvimento do ensino e para realização de atividades da administração tributária, como determinado, respectivamente, pelos arts. $198, \S 2^{\circ}$, 212 e 37, XXII, e a prestação de garantias às operações de crédito por antecipação de receita, previstas no art. $165, \S 8^{\circ}$, bem como o disposto no $\S 4^{\circ}$ deste artigo;
}

As Contribuições Sociais são a fonte orçamentária justa e ideal para financiar toda e qualquer espécie de direitos sociais. Os fundamentos principais desta escolha se deve à característica essencial das contribuições que é a vinculação das suas receitas e, também, por que este tributo é de competência da União e suas receitas irão compor o orçamento público de alcance federal. Neste aspecto federativo a União teria que distribuir verbas para os demais membros federados pelo atual sistema de composição de receitas de transferência obrigatória.

\section{VINCULAÇÃO DAS RECEITAS DA CONTRIBUIÇÃO SOCIAL PARA EFETIVIDADE DOS DIREITOS DOS TRANS OU INTERSEXUAIS}

As Contribuições Sociais surgiram à luz do ideário de justiça distributiva e da solidariedade, com escopo de reduzir as desigualdades. Sob este fundamento axiológico temse, atualmente, previsão constitucional do Sistema da Seguridade Social. Para tanto o legislador constituinte indicou tais tributos para serem a fonte mais importante para o financiamento dos direitos que compõem este sistema.

O dever de enfrentar as desigualdades no Brasil, promover a dignidade da pessoa humana são fundamentos, objetivos e princípios que justificam a existência do Estado:

Art. $1^{\circ}$ A República Federativa do Brasil, formada pela união indissolúvel dos Estados e Municípios e do Distrito Federal, constitui-se em Estado Democrático de Direito e tem como fundamentos:

III - a dignidade da pessoa humana;

Art. $3^{\circ}$ Constituem objetivos fundamentais da República Federativa do Brasil:

I - construir uma sociedade livre, justa e solidária; 
IV - promover o bem de todos, sem preconceitos de origem, raça, sexo, cor, idade e quaisquer outras formas de discriminação.

A efetividade dos compromissos referidos certamente dependerá de recursos financeiros. O grau de essencialidade dos direitos sociais está sublinhado em várias passagens do texto constitucional. Garantir estes direitos inclusive à população trans e intersexual no nível de Política de Estado estará em conformidade com os fundamentos supra referidos.

Para alcançar o nível de Política de Estado será necessário apresentar proposta de emenda à Constituição (PEC) para incluir, de modo explícito, a população trans e intersexual. Somente assim os governos não terão discricionariedade para destinar ou não receitas ao sistema de seguridade social para esta população. Afinal, são cidadãs(ãos) e contribuintes brasileiros. E, nesta condição se equiparam a todos os demais contribuintes do Sistema Tributário Nacional.

Sugere-se a seguinte redação para uma possível Proposta de Emenda Constitucional ( Art. 59, I, da CF/88), com a seguinte redação:

\footnotetext{
Art. 196. A saúde é direito de todos e dever do Estado, garantido mediante políticas sociais e econômicas que visem à redução do risco de doença e de outros agravos e ao acesso universal e igualitário às ações e serviços para sua promoção, proteção e recuperação.

Parágrafo único - Dentre as políticas a que se refere o caput devem ser garantidas aquelas destinadas às populações inter e transexuais.

Art. 201. A previdência social será organizada sob a forma de regime geral, de caráter contributivo e de filiação obrigatória, observados critérios que preservem o equilíbrio financeiro e atuarial, e atenderá, nos termos da lei, a:

$\S 14$ - o sistema de previdência social a que se refere este artigo deverá garantir tais direitos para a população inter e transexual.

Art. 203. A assistência social será prestada a quem dela necessitar, independentemente de contribuição à seguridade social, e tem por objetivos:

Parágrafo único - $\mathrm{O}$ sistema de assistência social à que se refere este artigo deverá incluir políticas de atendimento para a população inter e transexual.

Art. 206. O ensino será ministrado com base nos seguintes princípios:

VI - gestão democrática do ensino público que inclui conteúdos programáticos de diversidades culturais e de gêneros, na forma da lei;
}

A proposta apresentada neste estudo tem por finalidade garantir que as políticas públicas de inclusão da população trans e intersexual no sistema de seguridade social sejam efetivamente asseguradas, ou seja, tenham o nível de Política de Estado tal qual é assegurado para toda a população do Brasil.

A realidade de exclusão da população trans e intersexual da tutela estatal, já apresentada nesta pesquisa, comprova as graves consequências do descaso político dos governantes que não consideram esta população no mesmo nível das demais populações. 
No que diz respeito ao orçamento público, este é regido principalmente por três leis: a Lei de Diretrizes Orçamentária (LDO), elaborada anualmente: a Lei Orçamentária Anual (LOA); e, o Plano Plurianual (PPA) que tem o escopo de gerir o orçamento público durante os quatro anos do mandado presidencial. Neste contexto ressalte-se que no art. 195 , $\S 2^{\circ}$ a Constituição determina que o orçamento da Seguridade Social deve respeitar as metas e prioridades estabelecidas na LDO:

$\S 2^{\mathbf{o}}$ A proposta de orçamento da seguridade social será elaborada de forma integrada pelos órgãos responsáveis pela saúde, previdência social e assistência social, tendo em vista as metas e prioridades estabelecidas na lei de diretrizes orçamentárias, assegurada a cada área a gestão de seus recursos.

Em que pese o legislador constitucional tenha dado liberdade ao governo para estabelecer tais metas e prioridades elas não podem desconsiderar as determinações constitucionais a respeito de Políticas do Estado. Para estas não há discricionariedade. A realidade de violência e exclusão já relatas permite defender que a confiança depositada no Poder Executivo para aplicação do orçamento público deve ser mitigada.

Faz-se necessário atrair para a constituição tais metas e prioridades citadas no Art. $195, \S 2^{\circ}$ da CF, além de princípios norteadores, limitando, portanto, a discricionariedade do Executivo para aplicar ou não o dinheiro público em Políticas Públicas que não tem dever constitucional de realizar.

A atual realidade da população ora em análise é a de lutar junto ao Judiciário para usufruir direitos, alcançados a partir de interpretação principiológica que se poderia indicar como ativismo judicial e não de judicialização. E diante deste embate tais brasileiros ficam à margem do Sistema de Seguridade Social embora para tal sistema assumam a condição de contribuintes.

\section{CONCLUSÕES}

Para esta pesquisa ficou pactuado que a população intersexual compreende os sujeitos que apresentam variações genéticas, físicas, ou anatômicas, nos cromossomos, gônadas e/ou órgãos genitais; e a comunidade transexual, os sujeitos em que as variações se atém à esfera psíquica do indivíduo, identificada pelo sentimento intenso de não pertencimento ao sexo anatômico. 
A realidade brasileira é a de que tais populações encontram-se marginalizadas de direitos, em destaque, neste estudo, os direitos sociais. Devem recorrer ao Judiciário para que lhes sejam reconhecidos direitos pois não há previsão explícita em nível constitucional ou legal. Ficam a depender de política de governo e de previsão orçamentária.

Para enfrentar todas estas dificuldades a presente pesquisa sugere que as exclusões que sofrem a população trans e intersexual sejam reconhecidas e a busca de soluções efetivas necessitam, inicialmente, galgar à condição de política de estado e não permanecer no nível de política de governo.

Para alcançar este nível e tendo em vista a realidade de exclusões de direitos, sugerese acrescentar de modo explícito no texto constitucional (nova redação) para que não mais fosse permitido a discricionariedade de governos quanto a tais políticas. Isso deverá ser trazido por meio de Emenda à Constituição (PEC), nos seguintes termos: nos direitos à saúde no Art. 196 acrescentar parágrafo único (Dentre as políticas a que se refere o caput devem ser garantidas aquelas destinadas às populações inter e transexuais); quanto à previdência social em seu artigo 201 acrescentar parágrafo 14 (O sistema de previdência social a que se refere este artigo deverá garantir tais direitos para a população inter e transexual); em face da assistência social em seu artigo 203 acrescentar parágrafo único (O sistema de assistência social à que se refere este artigo deverá incluir políticas de atendimento para a população inter e transexual); e, entre os princípios a serem observados para o ensino em seu artigo 206, VI, acrescentar que na gestão democrática do ensino sejam considerados, inclusive, conteúdos sobre as diversidades culturais e de gêneros.

A proposta da pesquisa avança para indicar que o financiamento de tais direitos poderia ser feito por meio das Contribuições Sociais. Esta escolha se deve pois já há previsão deste tributo no texto constitucional do Brasil para financiar a Seguridade Social. O regime jurídico destes tributos impõe a vinculação das receitas que, defende-se, é fundamental para garantir a efetividade das políticas públicas em um Estado Social.

Em face da proposta de que direitos sociais para inter e transexuais devem ter nível de política de estado defende-se que, possivelmente, haverá redução das desigualdades sociais e das atuais violências. Seria o reconhecimento de que se há o dever fundamental de pagar tributos também deve haver o direito destes contribuintes de usufruírem de parcela destas receitas tributárias. É uma questão de justiça tributária e social. 


\section{REFERÊNCIAS BIBLIOGRÁFICAS}

ALMEIDA, Cecília Barreto de. VASCONCELLOS, Victor Augusto. Transexuais: transpondo barreiras no mercado de trabalho em São Paulo? Revista de direito GV. Vol. 14. No 2. São Paulo: May/Aug. 2018. Disponível em: < https://doi.org/10.1590/2317-6172201814 >. Acesso em 29 ago. 2020.

APPIO, Eduardo. Controle Judicial das Políticas Públicas no Brasil. Curitiba: Juruá, 2005. Disponível em:

<https://repositorio.ufsc.br/bitstream/handle/123456789/87373/208502.pdf?sequence> Acesso em: 29 ago. 2020

BAHIA. Defensoria Pública do Estado. Entendo a diversidade sexual / Defensoria Pública do Estado da Bahia. - $1^{\text {a }}$. ed. - Salvador: ESDEP, 2018. 24 p. Disponível em: $<$ http://www.defensoria.ba.def.br/wp-content/uploads/2019/01/cartilha_diversidadesexual.pdf> Acesso em: 05 jun. 2019.

BENTO, Berenice. Quando o gênero se desloca da homossexualidade: homossexualidade entre transexuais. In Politica e cotidiano: estudos antropológicos sobre o gênero família e sexualidade. Organizadora: Miriam Pillar Grossi e Elisete Schwabe. - Blumenau: Nova Letra, 2006. 336p.

BIAZON, Fábio. Respaldo e Problemas Jurídicos Enfrentados pelos Intersexuais:

Avanços e Estagnação de seus Direitos. VII Congresso de Direito da Universidade Estadual de Londrina: "Democracia" Curso de Mestrado em Direito Negocial da Universidade Estadual de Londrina Comunicações de Trabalhos Científicos. Londrina, 2018. ISSN: 19823452 .

BRASIL (2017), Processo Transexualizador no SUS. Ministério da Saúde. Disponível em: < http://portalms.saude.gov.br/atencao-especializada-e-hospitalar/especialidades/processotransexualizador-no-sus> Acesso em: 29 maio 2019.

BRASIL. Constituição Federal de 1988. Promulgada em 5 de outubro de 1988. Disponível em <http://www.planalto.gov.br/ccivil_03/constituicao/constituição.htm>. Acesso em: 05 jun. 2019.

BRASIL. Ministério da Saúde. Nota Técnica no 795/2017 - CGAE/DAET/SAS/MS. Brasília, 24 mai. 2017. Disponível em:

<http://www.consultaesic.cgu.gov.br/busca/dados/Lists/Pedido/Attachments/566216/RESPOS TA_PEDIDO_2196122_25_05_2017_CGAE.pdf> Acesso em: 05 jun. 2019.

BRASIL. Ministério da Saúde. Saúde: Atenção à integral saúde da população trans. 2016. Disponível em:

<http://portalarquivos2.saude.gov.br/images/pdf/2016/fevereiro/18/CARTILHA-Equidade10x15cm.pdf >. Acesso em: 05 jun. 2019. 
CAESAR, Gabriela. Quase 300 transgêneros esperam cirurgia na rede pública 10 anos após portaria do SUS. G1, 19 ago. 2018. Disponível em: <https://g1.globo.com/ciencia-esaude/noticia/2018/08/19/quase-300-transgeneros-esperam-cirurgia-na-rede-publica-10-anosapos-portaria-do-sus.ghtml>. Acesso em: 31 mar. 2019

CARVALHO, Paulo de Barros. Curso de direito tributário. 24a ed. São Paulo: Saraiva, 2012.

CARVALHO, Paulo de Barros. Direito Tributário - Linguagem e Método. $6^{\mathrm{a}}$ ed. São Paulo: Noeses, 2015.

CUNHA, Leandro Reinaldo da. Identidade e redesignação de gênero: aspectos da personalidade, da família e da responsabilidade civil. Rio de Janeiro: Lumen Juris, 2015.

ELALI, André. Tributação e Regulação Econômica: um exame da tributação como instrumento de regulação econômica na busca da redução das desigualdades regionais. São Paulo: Mp Editora, 2007.

FERRARO, Carolina Cantarelle. A Tredestinação das Contribuições Sociais. Revista de Finanças Públicas, Tributação e Desenvolvimento - RFPTD, v. 6, n.6, 2018. Disponível em: <https://www.e-publicacoes.uerj.br/index.php/rfptd/issue/view/1810>. Acesso em 14 abr. 2019.

HOLMES, Stephen. El costo de los derechos: Por qué la liberad depende de los impuestos. Buenos Aires: Siglo Ventuino Editores, 2012.

LENZA, Pedro. Direito Constitucional Esquematizado. 13. Ed. São Paulo: Saraiva, 2009.

MACEDO, Fabiana Farias de. Práticas pedagógicas e homofobia em escolas do cariri paraibano. Monografia apresentada ao Curso de Licenciatura em Ciências Sociais do Centro de Desenvolvimento Sustentável do Semiárido da Universidade Federal de Campina Grande. Sumé-PB, 2019. Disponível em <http://dspace.sti.ufcg.edu.br:8080/jspui/bitstream/riufcg/11842/1/FABIANA\%20FARIAS\% 20DE\%20MACEDO\%20-\%20TCC\%20CI\%C3\%8ANCIAS\%20SOCIAIS\%202019.pdf> Acesso em 29 ago. 2020.

MORAES, Alexandre de. Direito Constitucional. 33. Ed. São Paulo: Atlas, 2017. ISBN: 978-85-97-01129-6

MOREIRA, Fábio Vinícius Ferreira. Contribuição Social: A Importância do Tributo para o Financiamento da Assistência Social no Brasil. Revista Digital Constituição e Garantia de Direitos, v. 8, n. 1, p. 40 - 64, 28 out. 2015.

QUEIROGA, Louise. Brasil segue no primeiro lugar do ranking de assassinatos de transexuais. O Globo, 16 nov. 2018. Disponível em: <https://oglobo.globo.com/sociedade/brasil-segue-no-primeiro-lugar-do-ranking-deassassinatos-de-transexuais-23234780>. Acesso em 31 mar. 2019. 
ROCON, Pablo Cardozo. SODRÉ, Francis. ZAMBONI, Jésio. RODRIGUES, Alexsandro. ROSEIRO, Maria Carolina Fonseca Barbosa. O que esperam pessoas trans do Sistema Único de Saúde?. Interface (Botucatu). 2018; 22(64):43-53. DOI: 10.1590/1807-

57622016.0712. Disponível em: <http://www.scielo.br/pdf/icse/v22n64/1807-5762-icse1807-576220160712.pdf> Acesso em: 05 jun. 2019.

SORG, Letícia. Ninguém é $100 \%$ homem ou $100 \%$ mulher. Somos todos intersexuais. ÉPOCA, 22 jul. 2009. Disponível em:

$<$ http://colunas.revistaepoca.globo.com/mulher7por7/2009/07/22/ninguem-e-100-homem-ou100-mulher-estamos-todos-no-meio/>. Acessado em 07 abr. 2019.

VEDROSSI, Fernanda. Transfobia no ambiente escolar. 2013. Disponível em:

<https://monografias.brasilescola.uol.com.br/educacao/transfobia-no-ambiente-escolar.htm>. Acesso em 31 mar. 2019. 